\title{
Linfoma de células T del adulto asociado a
}

\section{HTLV-1}

HTLV-1 associated adult T-cell lymphoma

\section{Lucía Giraldoㄹ, Santiago Arizaㅁ, Rocío Orduz², Fernando Palma²}

1. Fundación Universitaria de Ciencias de la Salud, Hospital San José, Bogotá, D.C., Colombia

2. Clínica Universitaria Colombia, Clínica Colsanitas, S. A., Grupo de Investigación, INPAC, Bogotá, D.C., Colombia

\section{RESUMEN}

El linfoma de células T del adulto es una neoplasia maligna de linfocitos T periféricos causada por el HTLV-1 (Human T-cell Lymphotropic Virus, type 1), endémico en Colombia. Se presenta un paciente de sexo masculino de 66 años de edad que consultó por la aparición de lesiones en la piel del tronco y las extremidades. El reporte de patología determinó el diagnóstico de linfoma T periférico NOS (sin otra especificación). Se inició el tratamiento local de las lesiones con fototerapia, con empeoramiento de estas, razón por la cual se sospechó y se confirmó el diagnóstico de linfoma de células T del adulto asociado a HTLV-1.

Los dermatólogos deben estar familiarizados con la enfermedad y conocer sus diferentes manifestaciones cutáneas que, en ocasiones, simulan una micosis fungoides, con el fin de identificar de manera más oportuna los casos.

PALABRAS CLAVE: virus 1 linfotrópico T humano; terapia antirretroviral altamente activa; interferón alfa; linfoma cutáneo de células T; serología; quimioterapia combinada.

\section{SUMMARY}

The adult T-cell lymphoma is a peripheral T-cell neoplasm caused by the human T-cell lymphotropic virus, type 1 (HTLV-1), endemic in Colombia. We present the case of a 66 years-old male patient who presented with skin lesions in trunk and extremities. The pathology study established the diagnosis of peripheral T-cell lymphoma NOS (not otherwise specified). Local management of skin lesions started, but it progressed, so adult T-cell lymphoma was suspected and confirmed.

Colombia is an endemic country for HTLV-1. Dermatologists should be familiar with this malignancy and its different skin manifestations, occasionally simulating mycosis fungoides, in order to identify more cases in a timely manner.

KEY WORDS: Human T-lymphotropic virus 1; antiretroviral therapy, highly active: interferon-alpha; lymphoma, T-cell, cutaneous; serology; drug therapy, combination.
Correspondencia:

Lucía Giraldo

Email:

luciagir@gmail.com

Recibido: 31/05/2016

Aceptado: 27/03/2017

Conflictos de interés:

No se reportan conflictos de interés.

Financiación:

Ninguna. 
El linfoma de células $\mathrm{T}$ del adulto es una neoplasia maligna de linfocitos $\mathrm{T}$ periféricos causada por el HTLV-1 (Human T-cell Lymphotropic Virus, type 1), el cual es endémico en Colombia y, también, causa paraparesia espástica tropical.

El linfoma de células $\mathrm{T}$ del adulto frecuentemente presenta manifestaciones cutáneas que los dermatólogos deben conocer. Existen cuatro variantes clínicas de la enfermedad: la forma latente, la crónica, la linfomatosa y la leucémica aguda. El pronóstico de las dos últimas es pobre en comparación con otros linfomas no Hodgkin agresivos ${ }^{(1)}$. Se presenta el seguimiento durante dos años y seis meses de un caso ilustrativo de la enfermedad, con importante compromiso en piel y su reacción al tratamiento.

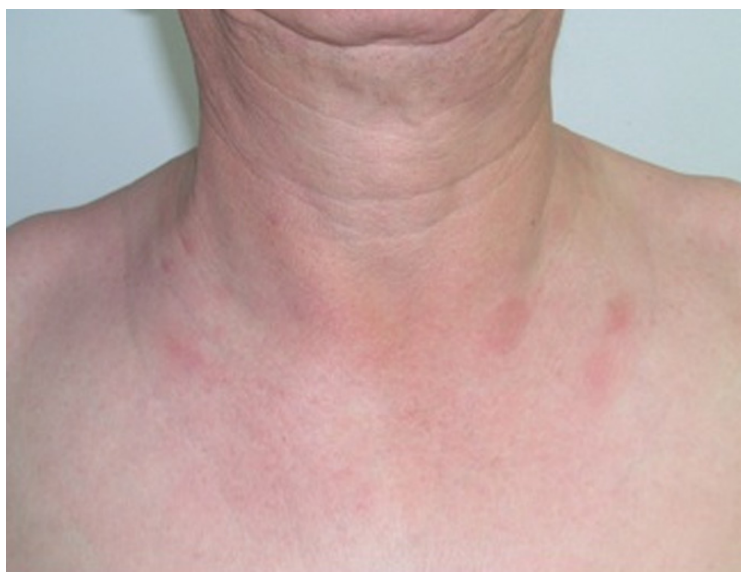

Figura 1. Pápulas y placas eritematosas en el tronco

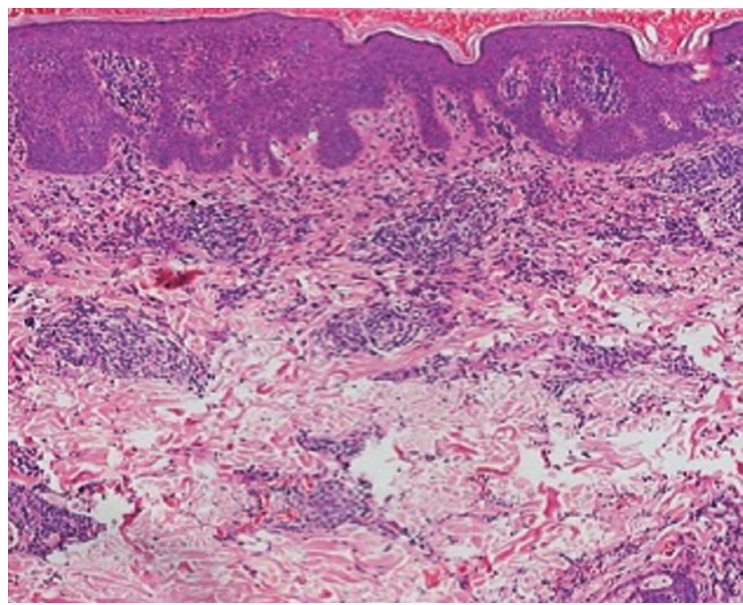

Figura 3. Hiperplasia epidérmica y, en la dermis, infiltrado linfoide atípico superficial y profundo con distribución perianexial. Hematoxilina y eosina, 4X.

\section{PRESENTACIÓN DEL CASO}

Se presenta un paciente de sexo masculino de 66 años de edad sin antecedentes relevantes, que consultó por la aparición de pápulas y placas eritematosas pruriginosas de nueve meses de evolución en el tronco y las extremidades (figuras 1 y 2).

En la biopsia de piel inicial se encontró hiperplasia epidérmica y, en la dermis, infiltrado linfoide atípico superficial y profundo con distribución perianexial (figuras 3 y 4). La inmunohistoquímica fue positiva para $\mathrm{CD}_{3}$, CD4 y CD5, y negativa para $\mathrm{CD} 8, \mathrm{CD}_{30}, \mathrm{CD}_{5} 6$, CD2o y Tdt (figuras 5 y 6). El reporte de patología determinó el diagnóstico de linfoma T periférico (sin especificación del subtipo), pero se sugirió un ELISA para el HTLV 1-2.

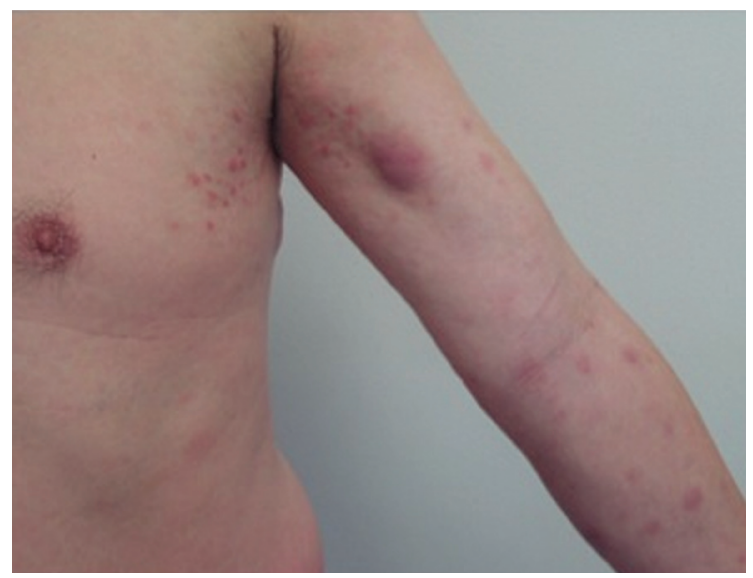

Figura 2. Pápulas, placas y nódulos en las extremidades superiores

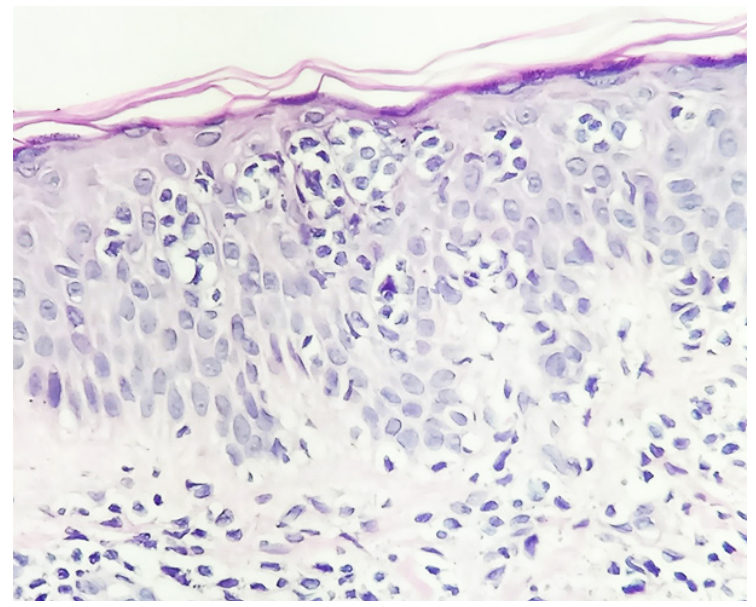

Figura 4. Infiltrado linfoide atípico. Hematoxilina y eosina, $4 \mathrm{X}$. 


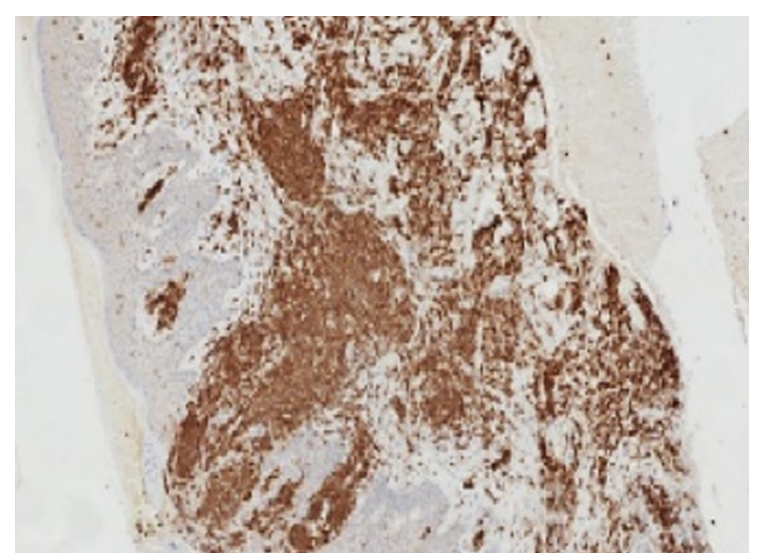

Figura 5. Estudio de inmunohistoquímica positivo para $\mathrm{CD}_{3}, 4 \mathrm{X}$.

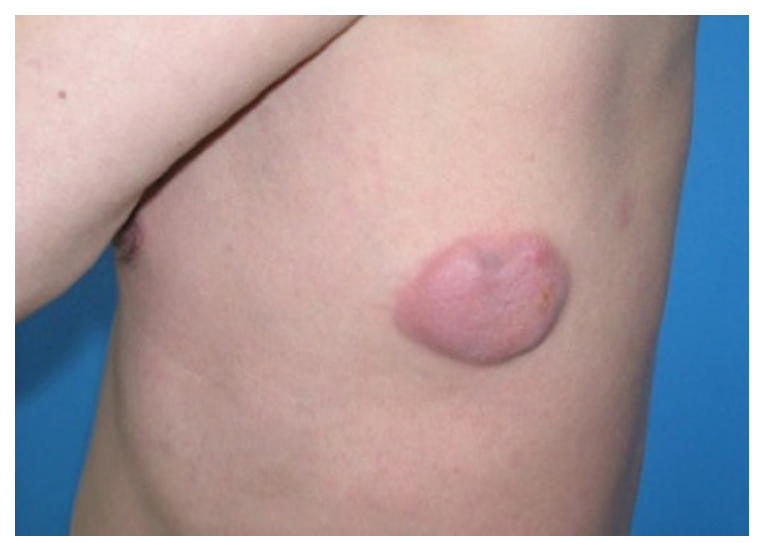

Figura 7. Nódulos y tumores después del tratamiento inicial con PUVA (costado izquierdo)

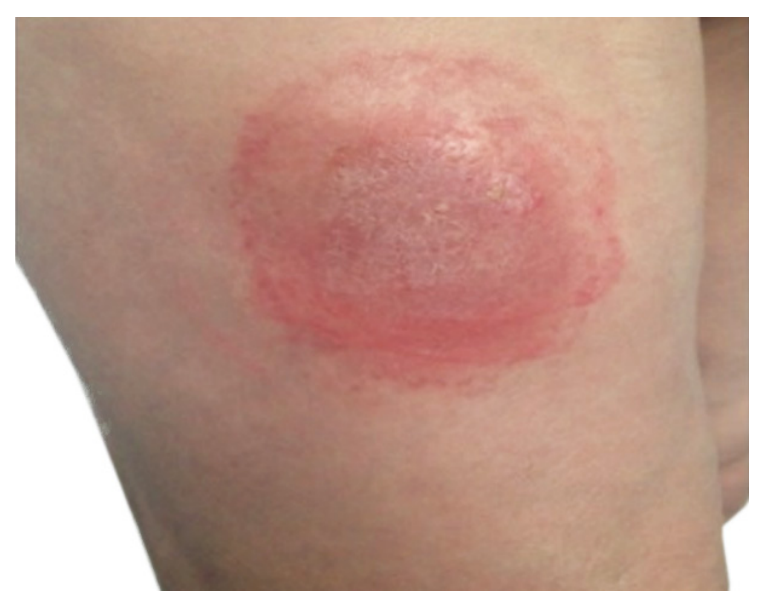

Figura 9. Lesión tumoral durante la recaída cutánea en el miembro inferior derecho

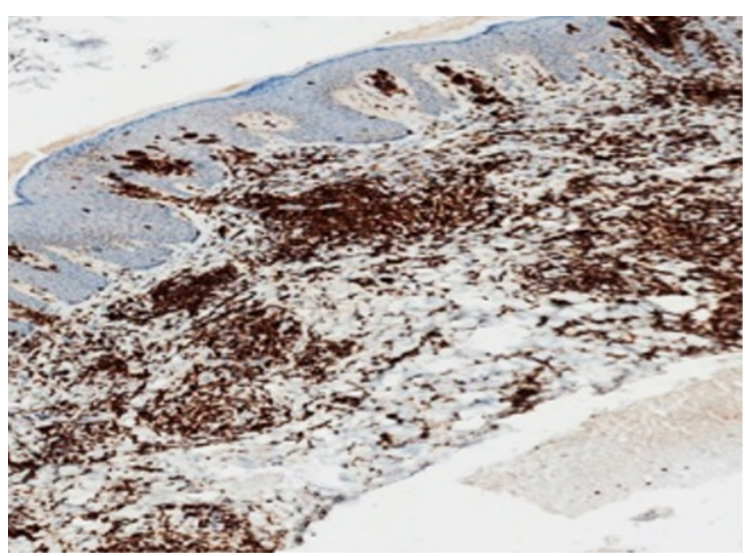

Figura 6. Estudio de inmunohistoquímica positivo para $\mathrm{CD} 4,4 \mathrm{X}$.

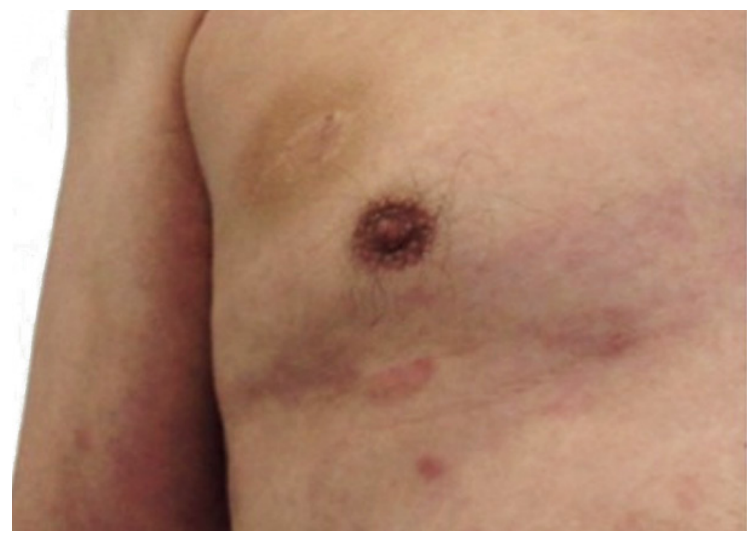

Figura 8. Mejoría de las lesiones después de la HAART (Highly Active Antiretroviral Therapy) y la radioterapia

Se inició el tratamiento local de las lesiones con fototerapia PUVA, produciéndose empeoramiento del cuadro clínico y aparición de nódulos y tumores, por lo que se sospechó un linfoma de células T del adulto asociado a HTLV-1 (figura 7). La serología para HTLV-1 fue positiva y la prueba de western blot confirmó la presencia de las proteínas (rgp46-I, P53, gp46, p36, p32, p28, p26, p24, p19 y GD21) del HTLV.

Teniendo en cuenta que los estudios de extensión descartaron compromiso de la sangre y la médula ósea, se clasificó el caso como una variante clínica latente y se manejó con terapia antirretroviral altamente efectiva (Highly Active Antirretroviral Therapy, HAART) (lamivudina más zidovudina), interferón alfa 2 beta y radioterapia localizada en las lesiones.

Hubo un buen control de la enfermedad durante dos años y medio de tratamiento (figura 8). Posteriormente, se presentó progresión de la enfermedad 
y se desarrolló compromiso ganglionar, por lo que el Servicio de Hematología inició poliquimioterapia. Durante el tiempo de remisión, se practicaron estudios para trasplante de médula ósea. Actualmente, el paciente se encuentra en recaída cutánea (figura 9).

\section{DISCUSIÓN}

El HTLV-1 es endémico en el sureste de Japón, el Caribe, el África intertropical, el Oriente Medio y Suramérica. Se estima que existen en el mundo de 5 a 20 millones de personas infectadas con el virus; sin embargo, el riesgo de desarrollar linfoma de células $\mathrm{T}$ del adulto en pacientes infectados con el virus es tan solo de 3 a $5 \%{ }^{(1)}$.

La forma de transmisión es por contacto con familiares cercanos, madre a hijo, durante la lactancia materna, por relaciones sexuales y por transfusiones de sangre ${ }^{(1,2)}$.

Este retrovirus tiene la capacidad de generar oncogénesis, expresando la proteína TAX en las células infectadas y silenciando el gen $\mathrm{P}_{53}$, supresor del tumor ${ }^{(1)}$.

Las manifestaciones cutáneas se presentan en 39 a $57 \%$ de los casos, con mayor frecuencia en los subtipos crónicos y latentes, y se caracteriza por la aparición de placas, pápulas, tumores o eritrodermia, que frecuentemente simulan una micosis fungoides. Entre sus manifestaciones sistémicas, se encuentran: linfadenopatía generalizada, hepatoesplenomegalia, leucocitosis, hipercalcemia e infecciones oportunistas ${ }^{(1,3)}$.

El diagnóstico se hace mediante la correlación de las manifestaciones clínicas, la histopatología y la serología para HTLV-1, y se confirma con el western blot $^{(1,2,45)}$.
El tratamiento de las formas agudas se basa en esquemas de poliquimioterapia, con un trasplante alogénico posterior o sin él. En las formas crónicas y latentes, el tratamiento con antirretrovirales e inteferón alfa 2 beta ha demostrado mejores porcentajes de supervivencia que la quimioterapia ${ }^{(1,4,6)}$.

Colombia es un país endémico para el HTLV-1 y, aunque el desarrollo del linfoma de células $\mathrm{T}$ del adulto es raro, los dermatólogos deben estar familiarizados con la enfermedad y conocer sus diferentes manifestaciones cutáneas que, en ocasiones, simulan la micosis fungoides, con el fin de identificar de manera más oportuna los casos.

Se recomienda que a todo paciente con diagnóstico de linfoma T se le practique un ELISA para HTLV 1-2, ya que el diagnóstico histopatológico del linfoma T del adulto no es fácil y, aunque se puede sospechar, en nuestro medio solo en pocos centros están disponibles todos los marcadores necesarios de inmunohistoquímica y el estudio de 'clonalidad' del virus en el tejido ${ }^{\text {(5). }}$.

La variante latente es la que presenta mejor pronóstico y la terapia HAART es la primera elección en este subtipo; en el presente caso, se obtuvo un excelente control de la enfermedad durante dos años y medio. Siempre debe considerarse un tratamiento médico inicial menos intensivo con HAART, postergando la quimioterapia para cuando se presente progresión de la enfermedad.

\section{..."El HTLV-1 es endémico en el sureste de Japón, el Caribe, el África intertropical, el Oriente Medio y Suramérica. Se estima que existen en el mundo de 5 a 20 millones de personas infectadas con el virus; sin embargo, el riesgo de desarrollar linfoma de células T del adulto en pacientes infectados con el virus es tan solo de} 3 a $5 \% "$ 


\section{CONCLUSIONES}

Colombia es un país endémico para el HTLV-1 y, aunque el desarrollo del linfoma de células $\mathrm{T}$ del adulto es raro, los dermatólogos deben estar familiarizados con la enfermedad y conocer sus diferentes manifestaciones cutáneas que, en ocasiones, simulan la micosis fungoides, con el fin de identificar de manera más oportuna los casos.

Se recomienda que a todo paciente con diagnóstico de linfoma T se le practique un ELISA para el HTLV 1-2.

La variante latente es la que presenta mejor pronóstico y la terapia HAART es la primera elección en este subtipo; en este caso, se obtuvo excelente control de la enfermedad durante dos años y medio.

\section{REFERENCIAS}

1. Ishitsuka K, Tamura K. Human T-cell leukaemia virus type I and adult T-cell leukaemia-lymphoma. Lancet Oncol. 2014;15:e517-26.

2. Marchetti MA, Pulitzer MP, Myskowski PL, Dusza SW, Lunning MA, Horwitz SM, et al. Cutaneous manifestations of human T-cell lymphotrophic virus type-1-associated adult T-cell leukemia/lymphoma: A single-center, retrospective study. J Am Acad Dermatol. 2015;72:293-301.

3. Mirvish JJ, Pomerantz RG, Falo LD, Geskin LJ. Role of infectious agents in cutaneous T-cell lymphoma: Facts and controversies. Clin Dermatol. 2013;31:423-31.

4. Nasr R, El Hajj H, Kfoury Y, de Thé H, Hermine O, Bazarbachi A. Controversies in targeted therapy of adult T cell leukemia/lymphoma: ON target or OFF target effects? Viruses. 2011;3:750-69.

5. Medina EA, Orduz R, Morales OL, Martínez Ó, Baldión M, Isaza MA. Adult T-cell leukemia/lymphoma in HTLV-1 infected patients: Report of two cases in Colombia. Biomédica. 2013;33:519-25.

6. Molina A, Molina V, Arroyave J. Linfoma de células T del adulto por HTLV1 con compromiso cutáneo. Reporte de caso. Rev Asoc Colomb Dermatol. 2011;19:167-71. 